\title{
Globalization or Localization: Global Brand Perception in Emerging Markets
}

\author{
Lily C Dong ${ }^{1} \&$ Chunling $\mathrm{Yu}^{2}$ \\ ${ }^{1}$ School of Management, University of Alaska Fairbanks, Fairbanks, Alaska, USA \\ ${ }^{2}$ School of Economics and Management, Tsinghua University, Beijing, China \\ Correspondence: Lily C Dong, School of Management, University of Alaska Fairbanks, PO Box 756080, \\ Fairbanks, AK 99775-6080, USA.
}

Received: August 14, 2020

doi:10.5539/ibr.v13n10p53
Accepted: September 4, 2020

Online Published: September 11, 2020

URL: https://doi.org/10.5539/ibr.v13n10p53

\begin{abstract}
With the globalization of world economy, more brands from emerging markets have entered the international market, which brought changes to the competitive landscape previously dominated by global brands from developed countries. It becomes more critical for marketing managers to understand consumers' perceptions of the two types of global brands: traditional global brands from developed countries and emerging global brands from developing countries, and to uncover the changes in consumers' purchase intentions in the new competitive environment. This study attempts to identify factors influencing consumers' purchase intentions concerning the aforementioned two types of global brands. The results indicated that consumers' interpretation of global brands is becoming increasingly complicated. In addition to the already established pathway of "perceived brand globalness (PBG)" influencing consumers' brand attitude (hereinafter referred to as "BA") and purchase intentions, there emerged a new pathway of "perceived brand localness (PBL)" influencing consumers' brand perception and purchase intentions. These two pathways have different effects on traditional global brands and emerging global brands. Specifically, for traditional global brands, PBG has greater influence than PBL; for emerging global brands, PBL has more influence than PBG.
\end{abstract}

Keywords: brand credibility, brand social identity, global brands, perceived brand globalness, perceived brand localness

\section{Introduction}

With the development of economic globalization in the late 1980s, consumers' preference for global brands has become an important topic in both practitioners and academians. Numerous studies have found that global brands represent product quality and brand prestige (Steenkamp, Batra, \& Alden, 2003; Ozsomer and Altaras, 2008; Strizhakova \& Coulter, 2015), and that consumers purchase global brands to show their social status (Belk, 1998; Escalas \& Bettman, 2003; Xie, Batra, \& Peng, 2015) or express self identity (Wu, Luo, Shroeder, \& Borgerson, 2017). This phenomenon is especially evident among consumers in the developing countries, as most global brands at the early stage of globalization came from the developed countries with more powerful economies than their home countries.

However, this situation is changing with the rise of emerging markets. An increasing number of brands from emerging markets, such as China's Huawei, Lenovo, and Xiaomi, India's Tata, and so on, have stepped onto the international stage and become global brands (Guo, 2013). For example, the annual sales of Huawei, the largest communications equipment manufacturer in the world, was 105.2 billion USD in 2018, of which $48.4 \%$ comes from the overseas markets, covering over 100 countries and regions. The rise of these global brands from developing countries (hereinafter referred to as emerging global brands) will certainly change the competitive landscape in a market originally dominated by global brands from developed countries (hereinafter referred to as traditional global brands) (Chan, Cui, \& Zhou, 2009). How consumers, especially those in developing countries, perceive the two types of global brands has become an important issue for marketing managers. Should managers of traditional global brands emphasize global brand image or create local brand image to appeal to consumers? For example, in the Chinese market, Coca-Cola adopts the message of "bring love home," which is in line with the Chinese family-oriented culture. Starbucks and Häagen-Dazs offer mooncakes during the 
Mid-Autumn Festival, consistent with Chinese customs. Are these tactics more effective than establishing a global brand image? Should managers of emerging global brands follow in the steps of traditional global brands to establish "perceived brand globalness (PBG)" or cater to the rising national pride of domestic consumers and build local brand images (Dimofte, Johansson, \& Ronkainen, 2008). The evolution of global competition has inspired us to revisit old questions. How do consumers perceive global brands in a changing competitive environment? Which strategy is more effective for multinational corporations: globalization or localization?

This study takes consumers in China, the world's largest emerging market, as its research subject. It analyzes their perceptions of traditional global brands and emerging global brands, and identifies key factors influencing their purchase intentions. This paper contributes to the literature in three aspects. First, we study consumers' perceptions of global brands while taking into consideration of their country of origin, which provides a more wholesome picture of global brands. Specifically, we divide global brands into traditional global brands from the developed countries and emerging global brands from the developing countries, so as to better understand the evolution of consumers' perceptions about global brands during different stages of economic globalization process. Therefore, we are able to capture the dynamic development and contrast of global brands which can provide new insights on consumers' evolving relationships and attitudes toward global brands. In addition, it responds to the call for studies of global brands from different country of origin from prior literature (i.e., Balabanis \& Diamantopoulos, 2011).

Second, this paper expands and enriches our understanding of brand social identity theory in the context of globalization by discovering subconcepts of global identity (GI) and local identity (LI), which complements the existing literature on brand social identity. We also investigate global brand perception by uncovering the psychological variables of consumers by analyzing consumers' brand perceptions from the perspective of brand social identity. Previous research of branding and its psychological influence on consumers was limited to the more general and ambiguous concept of consumer identity. Our paper attempts to dissect this concept in more details by incorporating the influence of global brands. We further divide the concept of consumers' social identity into global identiy which is recognized globally, local identiy which is receognized locally, and then analyze how they are affected by brand globalization and localization. Our research complements the literature on brand social identity by studying its formation and connotation during the dynamic globalization process.

Third, this study offers new interpretation on influencing factors on global brand attitudes. For traditional global brands from developed countries, brand credibility has the highest impact on brand attitudes, accounting for $67.3 \%$ of difference in attitude; for emerging global brands from host country, local identity has the highest impact, accounting for $70.8 \%$ of difference in consumers' brand attitude. Therefore, it can be concluded that for traditional global brands, "hard" factors like product quality and brand credibility plays a more important role in influencing brand attitudes, whereas for emerging global brands from developing countries, "soft" factors such as consumers' local identity play a more important role.

Lastly, we offer new understanding of the trends in competitive environment in the emerging market. Research on emerging markets, including consumers' perception of global brands, the changing connotation of global brands - both traditional global brands from developed countries and emerging global brands from developing countries, demonstrates the dynamic competition between the two types of global brands during the transitioning process of emerging markets. This research is particularly important as the size of customer base is growing in emerging markets who accounts for an increasing portion of sales of global brands. The results of this study can be helpful to brand managers by offering implications when comtemplating brand strategies in emerging markets.

\section{Theoretical Framework and Hypotheses}

Researchers and practitioners have found brands to be a powerful tool for differentiating a product among competitors, signaling quality of products, hence creating competitive advantages for the company in the market. From consumers' perspective, brands can help reduce search time, mitigate risk, and provide psychological reinformcement and social acceptance (Clow \& Baack, 2016; Keller, 2013; Wu et al., 2017). Managing a company's brand image is an important component of the overall marketing strategy.

More recent research studies have explored how brands function in the context of global market. To further complicate the competition brandscape, there are both traditional and newer global brands, with the later emerging in developing countries and markets. How do consumers in those countries perceive the old/traditional global brands from foreign developed countries as compared to the locally produced, new/emerging global brands? Do the consumers in emerging markets treat the two types of global brands differently? If yes, what factors would influence the perception and purchase intentions when it comes to choosing between the two? We 
believe answers to these questions will be helpful for managers of both traditional and emerging global brands.

Brands can reduce risk and enhance image for consuemrs during their purchase decision process. On one hand, a credible brand can lower consumers' perceived risk and information processing cost, and increase perceived value (Erdem \& Swait, 1998; Erdem, Swait, \& Valenzuela, 2006; Hauser \& Wernerfelt, 1990). On the other hand, a consumer buys a brand not only because of product quality and features but also because the brand reflects his/her current or ideal self. Research based on social identity theory has indicated that consumers purchase specific brands, in part, to enhance this self-concept (Escalas \& Bettman, 2005; Berger \& Heath, 2007; Guzmán \& Paswan, 2009). This study analyzes the impact of PBG and "perceived brand localness (PBL)" on consumers' brand credibility and brand social identity, and consequently on their brand attitude (BA) and purchase intention.

\subsection{Brand Credibility and Perceived Brand Globalness/Perceived Brand Localness}

Brand credibility refers to the extent to which consumers rely on a product's brand to determine its functionality and quality, which depends on a firm's willingness and ability to meet its commitments (Erdem \& Swait, 2004). A firm can communicate brand credibility through investing more resources in a brand, fulfilling a brand's commitments, and demonstrating a firm's long-term support for a brand.

Brand credibility is the believability of the product information contained in a brand (Erdem, Swait \& Valenzuela, 2006). Perceived brand globalness (PBG) and perceived brand localness (PBL) both impact brand credibility among consumers (Özsomer \& Altaras, 2008; Xie et al., 2015). PBG represents strength and exoticness, and excitement, while PBL signals tradition, authenticity, and a down-to-earth style (Dimofte et al., 2008; Schuiling \& Kapferer, 2004).

When a brand has high PBG and is considered widely accepted by consumers worldwide, consumers will view this brand more credible. Global brands with high brand awareness in many markets can quickly gain brand credibility in a new market. Based on signaling theory and brand credibility, Özsomer \& Altaras (2008) posited that brand credibility explains why PBG can influence perceived brand quality and reputation, revealing consumers' psychological process of accepting global brands. When consumers believe a global brand possesses higher quality and prestige, they will place more trust in and have a more positive attitude toward these brands. The path of enhancing brand credibility through the perception of quality and prestige, is based on consumers' rational processing of brand information or historical knowledge (Clow \& Baack 2016). Thus, we propose the following hypothesis:

H1: PBG has a positive impact on brand credibility for both traditional global brands and emerging global brands.

Prior research has treated PBG and PBL as two entirely different variables, and has rarely investigated them in the same brand simultaneously. However, as more and more local brands from emerging markets enter the international stage and become global brands, while an increasing number of traditional global brands adopt localization strategies in host country markets, both PBG and PBL can be manifested in the same brand more frequently. In other words, a brand can simultaneously possess a highly globalized image and highly localized image. Strizhakova \& Coulter (2015) revealed that, in today's business environment, as global brands' sense of novelty weakens, consumer needs are becoming increasingly rational. Many consumers may prefer brands with a high degree of localization because these brands better satisfy their needs or give them a touch of authentic local culture.

Findings from existing research (Steenkamp et al., 2003; Strizhakova \& Coulter, 2015) indicate that consumers not only enjoy the perceived high quality and prestigious reputation represented by global brands, they also like the local elements embedded in the global brands, namely, "local icon" (Steenkamp et al., 2003). Those global brands containing local elements can better satisfy consumers' needs to identify with local cultures as well as entice deeper trust from consumers.

Take the Chinese consumers for example, global brands from the developed countries adopt localization strategies in China to appeal more to their needs, while emerging global brands can gain acceptance from consumers more easily because they are considered representative of local enterprises. Accordingly, brand localization can enhance consumers' level of satisfaction regarding specific demands, hence strengthen brand credibility. Therefore, we propose the following hypothesis:

H2: PBL has a positive effect on brand credibility for both traditional global brands and emerging global brands.

\subsection{Brand Social Identity and Perceived Brand Globalness/Perceived Brand Localness}

Brand social identity theory holds that consumers look to brands for status, personality, and sense of belonging 
(Escalas \& Bettman, 2003, 2005; Han, Nunes, \& Drèze, 2010), often considering these aspects as a form of personal identity (Fischer, Völckner, \& Sattler, 2010; Wu et al., 2017). A brand's social identity is a critical influencing factor on consumers' brand choices. Through purchasing and using the brands consistent with their personal identity, consumers express themselves and show others who they are and who they want to be (Belk, 1998; Batra, Ahuvia, \& Bagozzi, 2012; Escalas \& Bettman, 2003).

Zhang \& Khare (2009) proposed a global/local identity framework to study the psychological impact of globalization on consumers. Global identity refers to the belief from consumers that they belong to a global community and live a global lifestyle. It is reflected in the following psychological aspects: they interested in global activities, agree to the positive effects of globalization, and believe that people around the world have common characteristics. Local identity refers to consumers' belief that they belong to a local community and live a local lifestyle. The psychological representations include the following: they are interested in local activities, respect local traditions and customs, and have a sense of belonging to a locality (Tu, Khare, \& Zhang, 2012). Global and local identities are not antithetical to each other, and one person may have both global and local identities at the same time. Cannon \& Yaprak (2002) believed that both local cosmopolitans and global cosmopolitans exist. Strizhakova, Coulter, \& Price (2008) revealed that PBG is associated with global identity, which provides consumers a "passport" of global citizenship and makes it easier for them to perceive the value of being a member of the world (Torelli, Özsomer, Carvalho, Keh, \& Maehle, 2012). Xie et al. (2015) argued that PBG has an significant impact on the expression of consumer identity. Thus, we propose the following hypothesis:

H3: PBG has a positive impact on consumers' global identity for both traditional global brands and emerging global brands.

During the last four decades, when China has adopted an open economic policy and transitioned from the world's largest manufacturer to the largest consumer market, it has attracted the attention of numerous multinational firms. Most traditional global brands from developed countries have entered the Chinese market one after another (Chan et al., 2009; Dong \& Tian 2009). Chinese consumers have witnessed the rapid growth of the country's economy and its important role in the world market. When new emerging global brands from their home country enter the world arena of competition and start competing with traditional global brands head on, both at home and abroad, their national pride is inspired and their sense of belonging to the local culture is reinforced (Yu \& Dong, 2019; Chan et al., 2009). For example, Huawei has become a strong competitor with Apple in the mobile phone market, and Lenovo has merged IBM thinkpad. Huawei and Lenovo brands have gained more international recognition along with their market share as a result of global branding strategies. The perceived brand globalness (PBG) of these emerging global brands signals a successful journey from home country to world stage, which in turn inspires Chinese consumers' pride, and strengthens their desire and willingness to identify with and be associated to the local culture, which we simplify here as the concept of local identity (Strizhakova, Coulter \& Price, 2012). Therefore, we propose the following hypothesis, specific to the emerging global brands from China:

H4: For emerging global brands, PBG positively impacts consumers' local identity.

As economies grow and consumers become better informed of the market and more confident in their local culture, a global brand image alone may not suffice to attract business from those consumers. Prior research has found that marketing activities with a local cultural element tend to evoke local consumers' national pride and sense of belonging, which heightens their local identity (Tu et al., 2012). When a traditional global brand employs certain marketing tactics involving local elements, consumers will consider it a recognition of their own culture. When a emerging global brand employs marketing activies involving local elements, it resonates with consumers and evokes cultural confidence and sense of belonging. In reality, an increasing number of global brands now adopt local branding strategies to attract consumers when they enter host country markets. For example, Coca-Cola's message of "bring love home" and Häagen-Dazs' offering of mooncakes around time of China's widely celebrated moon festival are both local strategies developed for China, incorporating the country's traditional culture and customs. Dimofte et al. (2008) found that adapting to local cultures and consumer preferences as a signal feature of brands makes it easier to generate consumer resonance and foster local identity. We therefore propose the following hypothesis:

H5: For both traditional global brands and emerging global brands, PBL positively impacts consumers' local identity.

\subsection{Brand Credibility and Social Identity impact BA and Purchase Intentions}

A brand's credibility and social identity positively influence consumers' brand attitude (BA). Prior research has 
shown that global brands enjoy higher brand reputation and perceived quality, which can evoke a sense of superiority in consumers, hence are more appealing to consumers (Steenkamp et al., 2003). These studies proposed two pathways for global brands to influence consumers' BA and purchase intentions. One pathway is through brand quality and functionality, in that many global brands exhibit superior brand quality resulting in brand credibility which positively influence consumers' brand attitude and purchase intention (Erdem \& Swait, 1998; Erdem et al., 2006; Swait \& Erdem, 2007). Another pathway is through the psychological impact of a brand's social value, consumers' local and global identities, generated by global brands, can affect BA and purchase intentions (Zhang \& Khare, 2009; Xie et al., 2015). Thus, we propose the following hypotheses:

H6: Brand credibility positively impacts consumers' BA.

H7: Consumers' global identity positively impacts their BA.

H8: Consumers' local identity positively impacts their BA.

H9: BA positively impacts brand purchase intentions.

Based on the preceding discussion, the theoretical framework of this study is established, as shown in Fig. 1.

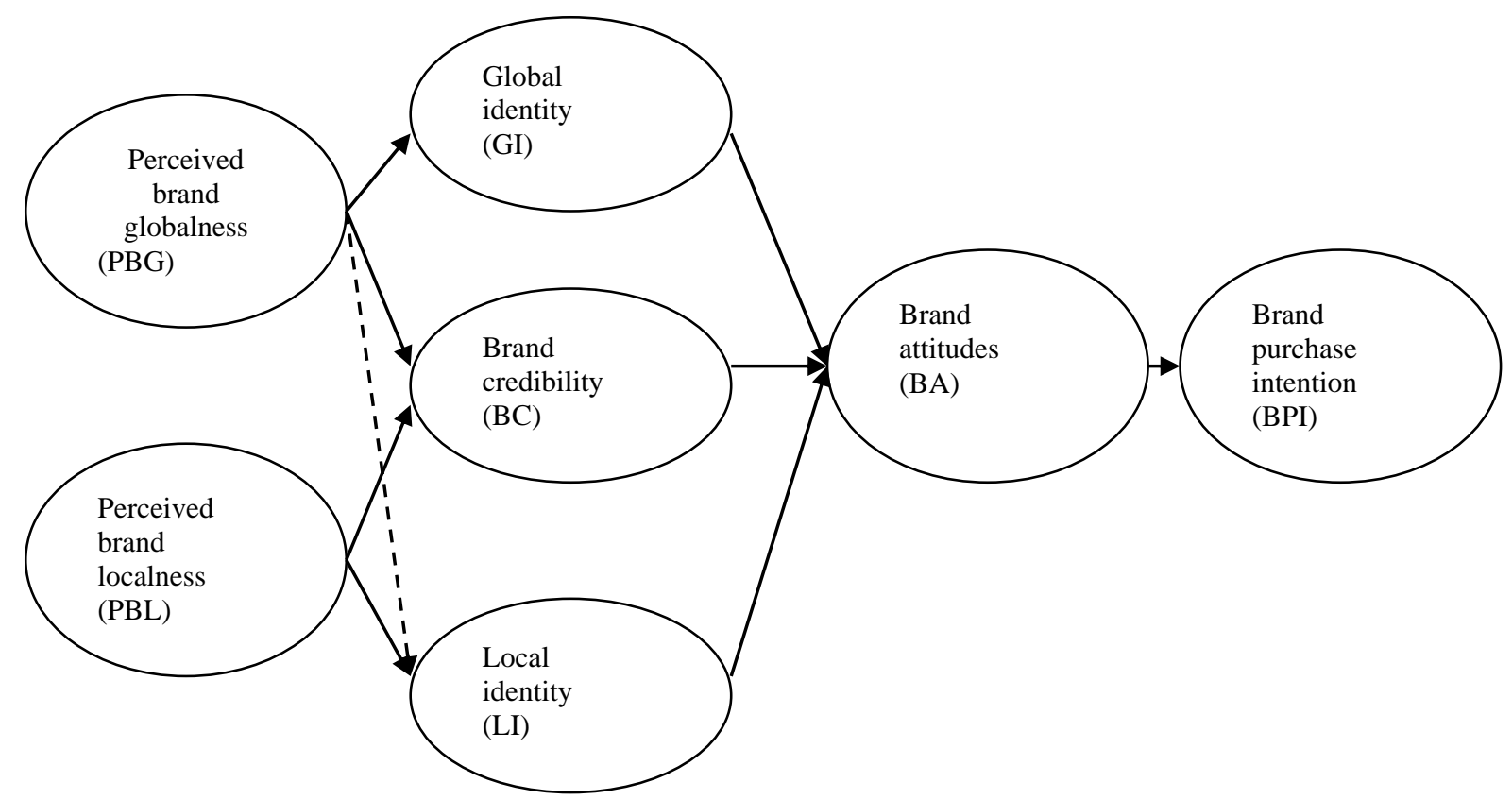

Figure 1. Factors Influencing Consumers' Attitudes Toward the Two Types of Global Brands

Note: Paths indicated by a solid line apply to both traditional and emerging global brands. The dotted line pathway applies only to emerging global brands.

\section{Methodology}

\subsection{Variable Measurements}

Most variables used in the study already have well established scales in the existing literature. The control variable, brand familiarity, may affect consumers' purchase intentions (Laroche, Kim, \& Zhou, 1996). In addition, since consumers' educational backgrounds, age, gender, and overseas experience may affect their cognition of global brands, hence are treated as control variables. The measurement items used in the study are shown in Table 1. 
Table 1. Variables and Measurement Items

\begin{tabular}{|c|c|c|}
\hline Variables & Measurement Items & Sources \\
\hline $\begin{array}{l}\text { Perceived brand } \\
\text { globalness } \\
\text { (PBG) }\end{array}$ & $\begin{array}{l}\text { 1) It is a global brand. } \\
\text { 2) Foreign consumers would purchase the brand. } \\
\text { 3) The brand can be purchased globally. }\end{array}$ & $\begin{array}{l}\text { Steenkamp et al., 2003; } \\
\text { Xie et al., } 2015\end{array}$ \\
\hline $\begin{array}{l}\text { Perceived brand } \\
\text { localness } \\
\text { (PBL) }\end{array}$ & $\begin{array}{l}\text { 1) This brand includes local improvements according to local consumers' } \\
\text { needs. } \\
\text { 2) Marketing strategies of the brand are localized in China. } \\
\text { 3) This brand can be purchased across China. } \\
\text { 4) This brand's marketing activities cater to local cultures and consumer } \\
\text { preferences. }\end{array}$ & Steenkamp et al., 2003 \\
\hline $\begin{array}{l}\text { Global identity } \\
\text { (GI) }\end{array}$ & $\begin{array}{l}\text { 1) Purchasing this brand makes me feel like I have become a part of the } \\
\text { global culture of consumption. } \\
\text { 2) Purchasing this brand makes me feel like I have become a global } \\
\text { citizen. } \\
\text { 3) Purchasing this brand makes me feel like I am linked to the world. } \\
\text { 4) Purchasing this brand arouses a sense of belonging to the global } \\
\text { culture of consumption in me. }\end{array}$ & $\begin{array}{l}\text { Strizhakova \& Coulter, } \\
\text { 2015; Tu, et al., } 2012\end{array}$ \\
\hline $\begin{array}{l}\text { Local identity } \\
\text { pride } \\
\text { (LIP) }\end{array}$ & $\begin{array}{l}\text { 1) Advertisements and other marketing activities of this brand arouse } \\
\text { national pride in me. } \\
\text { 2) Advertisements and other marketing activities of this brand make me } \\
\text { feel really good to be a member of my home country. } \\
\text { 3) Advertisements and other marketing activities of this brand arouse a } \\
\text { sense of belonging to my home country. }\end{array}$ & Tu et al., 2012 \\
\hline $\begin{array}{l}\text { Brand } \\
\text { credibility } \\
\text { (BC) }\end{array}$ & $\begin{array}{l}\text { 1) This brand's product announcements are credible. } \\
\text { 2) The brand name is credible. } \\
\text { 3) Products of the brand are consistent with their commitments. }\end{array}$ & Erdem \& Swait, 2004 \\
\hline $\begin{array}{l}\text { Brand attitudes } \\
\text { (BA) }\end{array}$ & $\begin{array}{l}\text { 1) This brand is excellent. } \\
\text { 2) I have positive comments about the brand. } \\
\text { 3) I like this brand. }\end{array}$ & Steenkamp et al., 2003 \\
\hline $\begin{array}{l}\text { Brand purchase } \\
\text { intention } \\
\text { (BPI) }\end{array}$ & $\begin{array}{l}\text { 1) I would consider this brand. } \\
\text { 2) I would choose this brand. } \\
\text { 3) I'd like to try the brand's new products. }\end{array}$ & $\begin{array}{c}\text { Dodds, Monroe, \& } \\
\text { Grewal, 1991; Petrevu \& } \\
\text { Lord, } 1994 \\
\end{array}$ \\
\hline $\begin{array}{l}\text { Brand } \\
\text { familiarity } \\
\text { (BF) }\end{array}$ & $\begin{array}{l}\text { 1) I'm familiar with this brand. } \\
\text { 2) I know the brand. } \\
\text { 3) I see advertisements about the brand frequently. } \\
\text { 4) People around me all know this brand. }\end{array}$ & Steenkamp et al., 2003 \\
\hline
\end{tabular}

\subsection{Data Collection}

To make the findings more generalizable, industry coverage and brand representativeness were taken into consideration when sample brands were selected (Steenkamp et al., 2003). Based on the performance of Chinese brands in the international market, we chose the food and beverage industry and electronics and appliance industry as subject of study, as there are local brands that grew into global brands in both industries. From each industry, we selected well-known global Chinese brands, one of traditional global brand and one of emerging global brand. The final brand set includes: Coca-Cola, Apple, Samsung, and Philips (traditional global brands); Tsingtao Brewery, Huawei, Lenovo, and Haier (emerging global brands).

For data collection, we employed a mulit-site, purposive sampling method. In hope of sampling respondents from Chinese consumers who are interested in and familiar with global brands, we selected all four of the Tier-1 cities which are known for their economic development and international exposure. Following is a brief discussion of the Chinese city tier system.

The Chinese city tier system is a hierarchical classification of cities in mainland China, which is commonly known and used among Chinese consumers, media, and businesses, though never officially recognized by any government agency. The classification is based on differences in consumer behavior, income level, population size, exposure to international culture and businesses, infrastructure, employment opportunities, as well as business opportunities. The first tier cities include: Beijing, Shanghai, Guangzhou, and Shenzhen, which are known as the most developed cities in the country, where most affluent and sophisticated consumers reside. Consumers in those cities possess all the ideal characteristics as samples for our study.

The main customer base in these cities are young and middle-aged professionals who are familiar with foreign (traditional) global brands and who also witnessed the booming of local brands in China's market. We hired a 
national market research company to conduct data collection. They sampled from those four cities mentioned above which resulted in 520 qualified subjects who completed our survey online, producing 260 completed questionnaires on traditional and 260 on emerging global brands. We offered incentive of 30 yuan RMB for each completed survey.

After questionnaires with missing data were excluded, 464 valid responses were obtained, comprising 226 questionnaires on emerging global brands and 238 on traditional global brands. Among the respondents, males constituted $53.0 \%$ and females constituted $47.0 \%$, a ratio close to China's overall population ratio of male/female ( $51.2 \%$ to $48.8 \%$ ), as indicated by the latest census published by National Bureau of Statistics of the People's Republic of China. Respondents aged 18-45 years, constituting $92.9 \%$ of the sample, and are part of a young and middle-aged consumer group with active consumption. They generally had a higher level of education, and $47.6 \%$ of them had experience of traveling/living overseas, which resulted in the ability to indedently identify and evaluate global brands.

\section{Analysis and Findings}

\subsection{Model Estimation and Construct Validity}

Before testing the hypotheses, we examined a correlation matrix of the composite scales for the key constructs and construct validity (See Table 2). Most of correlations were consistent with relationships' expectation. The mean for brand familiarity was 5.53, indicating that the subjects were familiar with the test brands. Mean values of BA, brand purchase intention, and other variables were greater than 4 , indicating that the study's respondents had positive attitudes toward global brands.

In terms of content validity, the theoretical model, variables, and evaluation items used in this study were based on detailed and accurate results of previous research and supported by numerous empirical studies. Regarding construct validity, a structural equation model was established using AMOS 21.0 for confirmatory factor analysis. The factor loading coefficients of structural variables corresponding to the evaluation items were greater than 0.8 . Average variance extracted (AVE) of all structural variables were greater than 0.5 , and composite reliability (CR) were greater than 0.8 , indicating that the observational variable could explain the structural variables and that the questionnaire had good construct validity. The overall goodness-of-fit indexes of the structural equation model were acceptable: GFI-0.892, RMSEA-0.064, and NFI, TLI, and CFI were all above 0.9.

Table 2. Correlations and Descriptive Statistics of Key Constructs

\begin{tabular}{|c|c|c|c|c|c|c|c|c|c|c|}
\hline & PBG & PBL & GI & LI & $\mathrm{BC}$ & BA & BPI & $\mathrm{M}(\mathrm{SD})$ & AVE & CR \\
\hline PBG & 1 & & & & & & & $5.74(1.25)$ & 0.82 & 0.90 \\
\hline PBL & .03 & 1 & & & & & & $5.17(1.75)$ & 0.75 & 0.89 \\
\hline GI & $.48 *$ & $.16^{*}$ & 1 & & & & & $4.32(2.00)$ & 0.87 & 0.85 \\
\hline LI & $.18^{*}$ & $.56^{*}$ & .02 & 1 & & & & $4.15(1.22)$ & 0.93 & 0.91 \\
\hline $\mathrm{BC}$ & $.32 *$ & $.30 *$ & $.19^{*}$ & $.12 *$ & 1 & & & $5.26(1.41)$ & 0.76 & 0.86 \\
\hline BA & $.31 *$ & $.35^{*}$ & $.27 *$ & $.32 *$ & $.45^{*}$ & 1 & & $4.94(2.03)$ & 0.79 & 0.92 \\
\hline BPI & $.34 *$ & $.27 *$ & $.32 *$ & $.28 *$ & $.32 *$ & $.56^{*}$ & 1 & $5.06(1.20)$ & 0.80 & 0.88 \\
\hline
\end{tabular}

*Correlation is significant at the .01 level (two-tailed tests)

\subsection{Analysis of Path Coefficients}

The test results of path coefficients are shown in Table 3. All the path coefficients were significant for both brand types (All path coefficients were significant at the 0.001 level, except for the influence path from global identity to BA for emerging global brands, where the significance level was 0.01). All the hypotheses were fully validated. One difference between emerging and traditional global brands is that the PBG of emerging global brands positively impacts consumers' local identity because the positive energy brought by domestic brands going global arouses patriotism and local identity in consumers. 
Table 3. Parameter Estimates (Standardized Structural Coefficients)

\begin{tabular}{cccc}
\hline Paths in the Structural Equation Model & Hypothesis & $\begin{array}{c}\text { Traditional } \\
\text { Global Brands }\end{array}$ & $\begin{array}{c}\text { Emerging } \\
\text { Global Brands }\end{array}$ \\
\hline Perceived brand globalness $\rightarrow$ Brand credibility & H1 & $0.481^{* * * *}$ & $0.288^{* * *}$ \\
Perceived brand localness $\rightarrow$ Brand credibility & H2 & $0.217^{* * *}$ & $0.674^{* * *}$ \\
Perceived brand globalness $\rightarrow$ Global identity & H3 & $0.374^{* * *}$ & $0.437^{* * *}$ \\
Perceived brand localness $\rightarrow$ Local identity & H4 & $0.371^{* * *}$ & $0.705^{* * *}$ \\
Brand credibility $\rightarrow$ BA & H5 & $0.673^{* * *}$ & $0.381^{* * *}$ \\
Global identity $\rightarrow$ BA & H6 & $0.213^{* * *}$ & $0.083^{* *}$ \\
Local identity $\rightarrow$ BA & H7 & $0.205^{* * *}$ & $0.708^{* * *}$ \\
BA $\rightarrow$ Brand purchase intention & H8 & $0.877^{* * *}$ & $0.803^{* * *}$ \\
Perceived brand globalness $\rightarrow$ Local identity & H9 & - & 0.193 \\
\hline
\end{tabular}

Note: ***means $\mathrm{P}<.001, * *$ means $\mathrm{P}<.01$

\subsection{Comparative Analysis of Path Coefficients for the Two Types of Global Brands}

\subsubsection{Influence of Perceived Brand Globalness and Perceived Brand Localness on BA and Purchase Intentions}

Table 4 shows the overall influence of PBG and PBL on BA and purchase intentions. When a consumer purchases a traditional global brand, the brand's PBG has greater impact than its PBL; when an emerging global brand is purchased, PBL has a greater impact. Thus, while traditional global brands have constantly promoted localization in host countries and emerging global brands have been pushing globalization, the significant factor influencing the attitudes and purchase intention of consumers in emerging markets is PBL, whether for purchasing traditional or emerging global brands. Especially for emerging global brands, PBL has a far greater influence on consumers' BA than PBG. Therefore, while promoting globalization, emerging global brands should continue to strengthen their PBL in host countries.

On the other hand, for traditional global brands trying to market in destination countries (markets), such as Coca Cola in China, it PBG is still a significant factor influencing consumers' BA $(0.403>0.222 ; 0.353>0.195)$, hence those brands should pursue a more comprehensive strategy instead of pushing for PBL alone. This finding is the opposite to the commonly believed opinion that global brands should pursue localization. We recommend that traditional global brands should maintain their PBG while trying to adapt to local culture and appeal to local customers.

Table 4. Influence of Perceived Brand Globalness and Perceived Brand Localness on BA and Purchase Intentions (Path Coefficients)

\begin{tabular}{ccc}
\hline Paths & Traditional & Emerging \\
Global Brands & Global Brands \\
\hline Perceived brand globalness $\rightarrow$ BA & 0.403 & 0.283 \\
Perceived brand globalness $\rightarrow$ Brand purchase & 0.353 & 0.227 \\
intention & 0.222 & 0.756 \\
Perceived brand localness $\rightarrow$ BA & 0.195 & 0.607 \\
Perceived brand localness $\rightarrow$ Brand purchase & intention &
\end{tabular}

\subsubsection{How Perceived Brand Globalness and Perceived Brand Localness Influence BA}

Table 5 shows the paths ofinfluence from perceived brand globalness and perceived brand localness on brand attitude (BA) . A comparative analysis indicates that, when consumers are purchasing traditional global brands, PBG and PBL influence consumers' brand attitudes through improving brand credibility. A plausible explanation is, traditional global brands have long been symbols of quality and prestige. Their products, produced under high-quality standards and consistent production processes, are sold around the world, hence they represent high brand credibility. Therefore, brand credibility is an important factor that drives consumers to purchase traditional global brands. Even enhancing brands' PBL works through improving brand credibility instead of through 
arousing consumers' local identity, to affect BA. For example, after seeing Coca-Cola's message of "bring love home," which permeates traditional Chinese culture, Chinese consumers' first reaction is trusting this brand and appreciating its effort to appeal to the local culture, then feel a sense of local identity. In other words, the PBL of traditional global brands has a weak impact on consumers' local identity.

When consumers purchase emerging global brands, PBG positively impacts consumers' local identity and brand credibility simultaneously, and further enhance their BA. PBL brings out consumers' positive BA by improving their local identity. As emerging global brands are having greater impact in the global market, consumers' national pride and local identity are aroused. Meanwhile, PBG enhances consumers' trust in local brands. Compared with PBG, PBL is more likely to enhance consumers' local identity, while contributing less to brand credibility.

Table 5. Paths of Influence from Perceived Brand Globalness/Perceived Brand Localness to BA (Path Coefficients)

\begin{tabular}{ccc}
\hline Perceived brand globalness $\rightarrow$ BA & Traditional & Emerging \\
Global Brands & Global Brands \\
\hline Through global identity & 0.080 & 0.036 \\
Through brand credibility & 0.324 & 0.110 \\
Through local identity & NA & 0.137 \\
\hline Perceived brand localness $\rightarrow$ BA & Traditional & Emerging \\
\hline Through local identity & Global Brands & Global Brands \\
\hline Through brand credibility & 0.076 & 0.499 \\
\hline
\end{tabular}

\subsubsection{Influence of Global Identity, Local Identity, and Brand Credibility on BA}

A comparative analysis of the influence of a brand's credibility and social identity on BA shows the following: 1) for traditional global brands, brand credibility has the greatest impact on consumers' BA, explaining $67.3 \%$ of their changes; 2) for emerging global brands, local identity has the greatest impact on consumers' BA, explaining $70.8 \%$ of their changes. Thus, product quality, reliability, and other objective factors play a greater role in consumer purchases of traditional global brands, while the psychological factor of local identity plays a more important role in the purchase of emerging global brands. This finding indicates that in today's global business environment, while traditional global brands are still symbols of high quality, an emerging global brand can appeal to consumers by inspiring/inciting local identity. Moreover, between the two psychological factors, global identity has little influence on consumers' attitudes toward emerging global brands. This indicates that consumers do not expect to project their global identity by purchasing emerging global brands. Instead, they place high value on a brand's credibility and strong local identity, resulting from its PBG. Brand credibility and local identity are significant variables that motivate consumers to purchase emerging global brands.

\section{Conclusions and Discussion}

With the rapid growth of emerging global brands, consumers' attitudes toward traditional global brands from developed markets and emerging global brands from developing markets are changing quietly. This study used a sample from the consumers in China, the world's largest developing country. It found that in addition to the well researched and already established (by previous research) factor of perceived brand globalization, perceived brand localness has become an important factor in influencing consumers' brand attitudes. Both factors influence consumers' BA and purchase intention through influencing a brand's credibility and social (including global and local) identities. The influencial factors and pathways toward brand attitudes are different for the two types of global brands. For traditional global brands, PBG has a greater impact, while PBL is more significant for emerging global brands. The former affects consumers brand attitudes primarily through improving brand credibility, while the latter influence consumers' brand attitudes through inciting their local identities.

\subsection{Theoretical Contributions}

The theoretical contributions of this paper are as follows. First, perceived brand globalization is studied here based on its country of origin. Previously, global brands were primarily tied to the developed countries which were globalized relatively early. As more brands from emerging markets enter the global stage as global brands, the competitive landscape of global brands has changed, which causes consumers' perception of global brands to be more complicated. By dividing global brands into traditional global brands from the developed countries and emerging global brands from the developing countries, we can better understand the evolution of consumers' 
perceptions of global brands during the dynamic development of economic globalization. This method responds to the marketing literature's call for research of global brands with consideration of the brands' origin (Balabanis \& Diamantopoulos, 2011). This research confirmed the different factors and pathways of influencing brand attitudes for the traditional and emerging global brands, which underscores the importance of studying the global brand perception while separating the brands based on their country of origin in the new competitive landscape.

Second, this paper enriches the brand social identity theory. Economic globalization has influenced consumer cultures and brand social identity in all countries. This research studies global brands in the context of of new competitive environment, and analyzes how consumers establish their identity through global brands under thedual influence of global consumption culture and national prideThe results indicate that a more accurate understanding of global brand social identity can be obtained by dividing brand identity into two parts: global identity and local identity.

\subsection{Practical Implications}

This study looks into global brand perception of consumers from emerging markets, under the new competitive business environment where local brands grow into global brands, hence provides managerial implications for global brand managers to help enhance their brand strategies.

\subsubsection{Implications for Managers of Traditional Global Brands in Destination Country}

For a long time, managers of traditional global brands who have entered a new market have been troubled by questions such as: should they adopt a localized or a globalized strategy? What features and characteristics of brands and products should be highlighted in marketing campaigns to attract more consumers? Findings from our research provide answers to these questions. First, although a local strategy has a positive impact on consumers' attitudes toward traditional global brands, its impact is limited, with the influence coefficient of PBL on consumers' BA at only 0.222 . PBG is still the critical variable that influences consumers' BA. Its influence is almost twice as large as that of PBL. This is because PBG can significantly improve consumers' trust in the brands and inspire a global identity. Second, traditional global brands should focus more on product quality and credibility. This study found that when consumers purchase traditional global brands, brand credibility has the greatest influence on their BA, even greater than psychological factors such as global and local identities. Thus, reliable product quality of traditional global brands is the most attractive factor to consumers. High quality and brand credibility have always been the basis for traditional global brands' success. With intensifying competition, foreign brands are no longer symbols of high quality, as it's occasionally reported that fake, low quality foreign-sourced products are found in the market. As a result, consumers have become more cautious when making purchases, and they make their purchase decisions by comparing product quality and features among various brands. As consumers' focus shifts to products themselves, foreign global brands should advertise their product performance more actively to create a good corporate image and improve consumers' brand favorability.

\subsubsection{Implications for Managers of Emerging Global Brands in Home Country}

After entering the international market, the key issue facing emerging global brands is whether to follow the steps of traditional global brands by reinforcing PBG or explore local elements to strengthen their brands' local identity. The findings of this study indicate that local identity significantly impacts consumers' purchases of emerging global brands. Local identity is influenced by PBG and PBL simultaneously. Therefore, emerging global brands should integrate globalization and localization strategies to enhance consumers' local identity. For example, they could highlight brands' presence in international markets to enhance consumers' national pride, or connect the brands with symbols of local culture to inspire consumers' sense of national belonging and local identity.

\subsection{Limitations and Future Research}

Limitations of our research lie in the selection of sample brands and subjects. In this study, brands were categorized roughly as either domestic or foreign global brands. This classification ignores the influence of consumers' attitudes towards different countries on their brand attitudes. The research participants in our study are consumers from China, which might limit the genernalizability of our findings. It is yet to be ascertained as whether these findings apply to consumers in other emerging markets.

Future research can explore the following issues. First, how country of origin of different global brands impact consumers' purchase of global brands. Take the Chinese consumers as an example, they are likely to boycott Japanese goods and hold a negative attitudes toward Japanese brands as a result of the influence of historical events. On the other hand, the Chinese consumers might have a positive attitude toward Amercain brands because they admire American heroism and individualist culture By exploring the impact of country of origin on 
consumers' brand attitude, future research will help us identify whether a brand's globalness or its country of origin would be a more important factor to influence brand attitudes.

Second, in-depth studies of the internal components of a brand's social identity and credibility should be conducted. This would include, for example, product quality, brand reputation, and corporate image. How do these factors affect brand credibility? How do consumers' global and local identities differ for global brands from different countries?

Lastly, further study can explore factors influencing consumers' global brand purchase intentions in different emerging markets. This paper only investigated the attitudes of Chinese consumers toward Chinese and traditional global brands, neglecting other emerging markets. With accelerating globalization, many global brands from other emerging countries have become increasingly influential. For example, the economic strength of India, Brazil, South Africa, and other countries is growing rapidly. These countries have significant difference from China in aspects of level of openness, national history and culture. Factors influencing consumers' BA and purchase intentions may also differ. These distinctions may lead to different results in an emerging market study even if the same theoretical model is used.

\section{Acknowledgements}

This paper was funded by the National Natural Science Foundation of China (no. 71272026).

\section{References}

Balabanis, G., \& Diamantopoulos, A. (2011). Gains and Losses from the Misperception of Brand Origin: The Role of Brand Strength and Country-of-Origin Image. Journal of International Marketing, 19(2), 95-116. https://doi.org/10.1509/jimk.19.2.95

Batra, R., Ahuvia, A., \& Bagozzi, R. P. (2012). Brand love. Journal of Marketing, 76(2), 1-16. https://doi.org/10.1509/jm.09.0339

Belk, R. W. (1998). Multimedia Consumer Research. Representation in Consumer Research, London: Routledge, 308,338 .

Berger, J., \& Heath, C. (2007). Where Consumers Diverge from Others: Identity Signaling and Product Domains. Journal of Consumer Research, 34(2), 121-134. https://doi.org/10.1086/519142

Cannon, H. M., \& Yaprak, A. (2002). Will the Real-World Citizen Please Stand up! The Many Faces of Cosmopolitan Consumer Behavior. Journal of International Marketing, 10(4), 30-52. https://doi.org/10.1509/jimk.10.4.30.19550

Chan, T. S., Cui, G., \& Zhou, N. (2009). Competition Between Foreign and Domestic Brands: A Study of Consumer Purchases in China. Journal of Global Marketing, 22(3), 181-197. https://doi.org/10.1080/08911760902845015

Clow, K. E., \& Baack, D. (2016). Integrated Advertising, Promotion, and Marketing Communications (7th ed.). Boston: Pearson.

Dimofte, C. V., Johansson, J. K., \& Ronkainen, I. A. (2008). Cognitive and Affective Reactions of US Consumers to Global Brands. Journal of International Marketing, 16(4), 113-135. https://doi.org/10.1509/jimk.16.4.113

Dodds, W. B., Monroe, K. B., \& Grewal, D. (1991). Effects of Price, Brand, and Store Information on Buyers' Product Evaluations. Journal of marketing research, 28(3), 307-319. https://doi.org/10.1177/002224379102800305

Dong, L., \& Tian, K. (2009). The Use of Western Brands in Asserting Chinese National Identity. Journal of Consumer Research, 36(3), 504-523. https://doi.org/10.1086/598970

Erdem, T., \& Swait, J. (1998). Brand Equity as a Signaling Phenomenon. Journal of consumer Psychology, 7(2), 131-157. https://doi.org/10.1207/s15327663jcp0702_02

Erdem, T., \& Swait, J. (2004). Brand Credibility, Brand Consideration, and Choice. Journal of consumer research, 31(1), 191-198. https://doi.org/10.1086/383434

Erdem, T., Swait, J., \& Valenzuela, A. (2006). Brands as Signals: A cross-country Validation Study. Journal of Marketing, 70(1), 34-49. https://doi.org/10.1509/jmkg.2006.70.1.34

Escalas, E. J., \& Bettman, J. R. (2003). You Are What They Eat: The Influence of Reference Groups on Consumers' Connections to Brands. Journal of Consumer Psychology, 13(3), 339-348. 
https://doi.org/10.1207/S15327663JCP1303_14

Escalas, E. J., \& Bettman, J. R. (2005). Self-Construal, Reference Groups, and Brand Meaning. Journal of Consumer Research, 32(3), 378-389. https://doi.org/10.1086/497549

Fischer, M., Völckner, F., \& Sattler, H. (2010). How Important Are Brands? A Cross-Category, Cross-Country Study. Journal of Marketing Research, 47(5), 823-839. https://doi.org/10.1509/jmkr.47.5.823

Guo, X. (2013). Living in a Global World: Influence of Consumer Global Orientation on Attitudes toward Global Brands from Developed Versus Emerging Countries. Journal of International Marketing, 21(1), 1-22. https://doi.org/10.1509/jim.12.0065

Guzmán, F., \& Paswan, A. K. (2009). Cultural Brands from Emerging Markets: Brand Image across Host and Home Countries. Journal of International Marketing, 17(3), 71-86. https://doi.org/10.1509/jimk.17.3.71

Han, Y. J., Nunes, J. C., \& Drèze, X. (2010). Signaling Status with Luxury Goods: The Role of Brand Prominence. Journal of Marketing, 74(4), 15-30. https://doi.org/10.1509/jmkg.74.4.015

Hauser, J. R., \& Wernerfelt, B. (1990). An evaluation cost model of consideration sets. Journal of Consumer Research, 16(4), 393-408. https://doi.org/10.1086/209225

Keller, K. L. (2013). Strategic Brand Management: Building, Measuring, and Managing Brand Equity (4th ed.). Boston: Pearson.

Laroche, M., Kim, C., \& Zhou, L. (1996). Brand Familiarity and Confidence as Determinants of Purchase Intention: An Empirical Rest in a Multiple Brand Context. Journal of Business Research, 37(2), 115-120. https://doi.org/10.1016/0148-2963(96)00056-2

Özsomer, A., \& Altaras, S. (2008). Global Brand Purchase Likelihood: A Critical Synthesis and an Integrated Conceptual Framework. Journal of International Marketing, 16(4), 1-28. https://doi.org/10.1509/jimk.16.4.1

Schuiling, I., \& Kapferer, J. N. (2004). Executive Insights: Real Differences between Local and International Brands: Strategic Implications for International Marketers. Journal of International Marketing, 12(4), 97-112. https://doi.org/10.1509/jimk.12.4.97.53217

Steenkamp, J. B., Batra, R., \& Alden, D. L. (2003). How Perceived Brand Globalness Creates Brand Value. Journal of International Business Studies, 34(1), 53-65. https://doi.org/10.1057/palgrave.jibs.8400002

Strizhakova, Y., \& Coulter, R. A. (2015). Drivers of Local Relative to Global Brand Purchases: A Contingency Approach. Journal of International Marketing, 23(1), 1-22. https://doi.org/10.1509/jim.14.0037

Strizhakova, Y., Coulter, R. A., \& Price, L. L. (2008). Branded Products as a Passport to Global Citizenship: Perspectives from Developed and Developing Countries. Journal of International Marketing, 16(4), 57-85. https://doi.org/10.1509/jimk.16.4.57

Strizhakova, Y., Coulter, R. A., \& Price, L. L. (2012). The young adult cohort in emerging markets: Assessing their glocal cultural identity in a global marketplace. Internal Journal of Research in Marketing, 29, 43-54. https://doi.org/10.1016/j.ijresmar.2011.08.002

Swait, J., \& Erdem, T. (2007). Brand Effects on Choice and Choice Set Formation under Uncertainty. Marketing Science, 26(5), 679-697. https://doi.org/10.1287/mksc.1060.0260

Torelli, C. J., Özsomer, A., Carvalho, S. W., Keh, H. T., \& Maehle, N. (2012). Brand Concepts as Representations of Human Values: Do Cultural Congruity and Compatibility between Values Matter? Journal of Marketing, 76(4), 92-108. https://doi.org/10.1509/jm.10.0400

Tu, L., Khare, A., \& Zhang, Y. (2012). A Short 8-Item Scale for Measuring Consumers' Local-Global Identity. International Journal of Research in Marketing, 29(1), 35-42. https://doi.org/10.1016/j.ijresmar.2011.07.003

Wu, Z., Luo, J., Schroeder, J. E., \& Borgerson, J. L. (2017). Forms of Inconspicuous Consumption: What Drives Inconspicuous Luxury Consumption in China? Marketing Theory, 17(4), 491-516. https://doi.org/10.1177/1470593117710983

Xie, Y., Batra, R., \& Peng, S. (2015). An Extended Model of Preference Formation between Global and Local Brands: The Roles of Identity Expressiveness, Trust, and Affect. Journal of International Marketing, 23(1), 50-71. https://doi.org/10.1509/jim.14.0009

Yu, C., \& Dong, L. (2019). Segmentation of young adult consumers in China: a global- local-cultural identity 
perspective. International Journal of Marketing studies, 11(1), 30-39.

https://doi.org/10.5539/ijms.v11n1p30

Zhang, Y., \& Khare, A. (2009). The Impact of Accessible Identities on the Evaluation of Global Versus Local Products. Journal of Consumer Research, 36(3), 524-537. https://doi.org/10.1086/598794

\section{Copyrights}

Copyright for this article is retained by the author(s), with first publication rights granted to the journal.

This is an open-access article distributed under the terms and conditions of the Creative Commons Attribution license (http://creativecommons.org/licenses/by/4.0/). 